\title{
Solving Asia’s Demographic Dilemmas
}

Japan has a new breed of modern young women, the "parasaito", according to Michael Zielenziger. ${ }^{1}$ These women choose career over marriage and family, despite Japan's endemic gender discrimination in the workplace. They live with their parents well into their twenties and thirties, and their favorite pastimes are shopping, traveling abroad and living for the moment. He refers to this as the "womb strike".

Fundamental changes have also swept through Japanese society. Until the 1970s, marriages were often arranged. For example, in Japanese companies and government ministries, one of the responsibilities of a senior ("sempai") was to find a wife for his junior ("kohai"). As recently as 1982, three in ten marriages were arranged. With modernization, there has been a decline in matchmaking, which means that young Japanese may have more difficulty meeting each other. The dramatic rise in non-regular employment is also changing the nature of working relationships in Japan.

Social relations in Japan would also be affected by its "homosocial society" says Zielenziger. Social life for most Japanese men involves drinking with other male colleagues. You only have to walk the streets of Tokyo to see salarymen drinking and eating together. At the same time, fancy restaurants and tea salons are full of well-dressed ladies gossiping together. This is why the Japanese government has been increasing its sponsorship of spouse-hunting events ("konkatsu") to encourage more people to marry and lift the nation's fertility rate. 
Then there are more than half a million young Japanese who you don't see, the social recluses (or "hikikomori") who avoid contact with the outside world and rarely leave the house. According to a Japanese cabinet survey, there would be 541,000 young Japanese aged between 15 and 39 leading such lives, who have not left their homes or interacted with others for at least six months. ${ }^{2}$ The hikikomori are typically men, rather than women, who suffer from anxiety or depression due to the shame associated with an experience of failure in life or the high expectations that society placed on them. They typically spend their days playing computer games and reading manga (Japanese comic books).

These socio-psychological factors would be some of the causes of the drop in Japan's fertility rate from 2.1 children per woman in 1974 to around 1.4 today, which is driving the aging of Japanese society and the decline in its population, thereby threatening the nation's prosperity (a fertility rate of 2.1 is necessary to maintain a country's population size and is called the "replacement rate").

China's fertility rate, which fell from around 2.7 children per woman in the 1980 s to around 1.7 today, has also been affected by socio-psychological factors, in particular China's "leftover women" ("sheng nu" in Mandarin). ${ }^{3}$ As everywhere, Chinese women are now much better educated and more career oriented than in the past. One consequence is that one in five Chinese women in the 25-29 age group would still be unmarried today in China. But even though China suffers from a shortage of women, as discussed in the previous chapter, the vast majority of Chinese men believe that women should be married by the age of 27 . And what's more China's notoriously macho men prefer to "marry down" in terms of age and educational attainment. In practical terms, this means that that A-quality guys will look for B-quality women, B-quality guys look for C-quality women and C-quality men look for D-quality women.

The net result of all of this is that China's best educated and most successful women find themselves unmarried (and so are China's least privileged men). And like Japan's parasaito girls, China's leftover women are not necessarily unhappy about that. While they are typically not against marriage, they also have other aspirations like career and travel. The main problem that China's leftover women have to deal with is the pressure from family, friends and even state-run media. In typical Chinese communist style, the national media seeks to stigmatize and bully leftover women into getting married and starting a family. After all, A-quality women are 
critical to China's future. As in Japan, some Chinese local governments are now in the business of organizing matchmaking events for leftover women.

But there is another demographic reality in Asia. Countries like India and Pakistan, where child marriage is still widespread and female education weak, have fertility rates of 2.5 and 3.3 children per woman, respectively. These fertility rates may be around half those of 50 years ago, but they are still sufficient to keep their populations young and growing. According to the UN, the population of India will overtake China's in 2022 , to become the world's most populous country. ${ }^{4}$

The Philippines is another country whose fertility rate is still relatively high at 3.1 children per woman. In this country where the Catholic Church still casts a strong influence over sex education, the availability of contraception and attitudes toward family planning, teenage pregnancies are the highest in Asia according to the UN. ${ }^{5}$ One in ten young Filipino women-between 15 and 19 years of age-is already a mother, a figure that has not declined over the past two decades, bucking the trend in the rest of Asia where teenage pregnancy has declined.

This demographic diversity in Asia between the low-birth and highbirth countries creates a great opportunity for mutually beneficial migration which we will explore later in this chapter. However, the sad reality is that demographic-deficit countries like Japan and Korea are not opening up sufficiently to this great opportunity, while demographic-surplus countries, like India and the Philippines, are facing immense challenges handling the colossal youth bulges entering their labor markets. Only Hong Kong and Singapore are seriously opening the gates to immigration, although only skilled migrants are treated decently in these economies.

But before we explore the issue of mutually beneficial migration, we must examine Asia's demographic transitions, and the manifold challenges of population bulges and population aging. Demographic dilemmas represent one of the greatest risks to the Asian Century.

\section{Asia’s Demographic Transitions}

East Asia's most advanced economies-Japan, Korea, Taiwan, Hong Kong, Singapore, China and Thailand-are in the midst of rapid population aging. ${ }^{6}$ In contrast to the others, China and Thailand will become "old" before they become rich. Another group of Asian economies, notably Bangladesh, India, Indonesia and the Philippines, have massive youth 
bulges now entering the jobs market. In this section, we will review demographic transitions sweeping Asian societies.

For much of human history, both birth and death rates were very high, such that populations only grew very slowly. But since economic development started taking off in Asia, the region has been experiencing major demographic transitions, meaning the transition from a high mortality and fertility pattern to a low mortality and fertility one, following the trend of Western countries in earlier times. The first demographic transition typically starts as mortality rates fall, especially for infants and children thanks to improved hygiene and nutrition as the economy develops. This leads to steep increases in the population, as the share of young and dependent people grows.

When this large group of youth advances into working age, this is the moment to reap the potential a "demographic dividend", as youthful and energetic workforces can drive their economies up the development ladder (the second demographic transition). This effect can be enhanced by a decline in fertility rates, due to the influence of urbanization, better education for women, improvement in women's rights and prosperity. This will reduce the numbers of dependent youth, and mean that a very large share of the population is of working age.

Economies like Japan, Korea, Taiwan, Hong Kong, Singapore and China have all benefited greatly from demographic dividends. Some economists argue that one-quarter or even one-third of their rapid economic growth was due to their demographic dividends. But their demographic dividends were not only due to large youth bulges. They also occurred thanks to their youth being well educated, and their strongly growing economies which created sufficient job opportunities. Economies like Bangladesh, India, Indonesia and the Philippines are at this very point now. But all the signs are that they will struggle to benefit as much from a demographic dividend due to their relatively poorer education systems, and also the incapacity of their economies to generate enough job opportunities.

When this demographic bulge advances into retirement age, we are in the midst of the third demographic transition, whose effect is enhanced by increased life expectancy thanks to improved access to health care and healthy lifestyles. Population aging, the rising share of senior citizens in the population, can act as a tax on the economy, as senior citizens are much less likely to work. As Japan, Korea, Taiwan, Hong Kong, Singapore and China are now all discovering, population aging can be very expensive 
for the public purse, or the purse of the extended family, because of the cost retirement income, and health and aged care expenses.

Lastly there is a fourth demographic transition which has surprised most demographers. That is where fertility rates fall and remain below the replacement rate of 2.1 children per woman, with the result that populations ultimately decline. Japan has led the world in this context, with its population falling from 128 million in 2010 to 127 million in 2016, and predicted to fall to 109 million by 2050 and further to 85 million by $2100,{ }^{7}$ with some estimating that before the year 4000 that we would see the end of the Japanese race. But Japan is not the only one to face the prospect of long-term population decline. A number of other countries are in a similar situation, especially many countries from East Europe (including the Ukraine and Bulgaria), and Central and Western Europe (such as Germany, Greece, Hungary and Italy), along with Puerto Rico in the Caribbean.

In the next section, we will explore India's demographic destiny and the challenge it faces in realizing a demographic dividend, before then moving onto the other end of Asia's demographic transitions, with the region's fading fertility and China's two-child policy.

\section{India's Demographic DEsTiny}

India, along with countries like Bangladesh, Indonesia and the Philippines, is in the midst of a major demographic transition. Life expectancy has leapt from just 41 years in 1960 to 68 in 2015 thanks notably to improvements in infant mortality. And while its fertility has fallen dramatically from almost 6 children per woman in 1960 to 2.4 in 2015, it still remains well above the replacement rate of 2.1 .

The net result is that India's population has boomed from 450 million in 1960 to some 1.3 billion today. Looking ahead, India's population is set to overtake China's by the year 2022 according to the UN, as we mentioned above. And by the year 2100, India's population could be 1.5 billion, some $50 \%$ higher than China's. Not only will India's population be bigger than China's, it will be very much younger for much of this period. For example, the median age of India's population in 2030 will be only 31, while China's will be 43 .

If population is power, then we should be looking more at India rather than China. 
The stark contrast between the demographic destinies of China and India is very much with us today. China's workforce started declining in 2012, while India's is in the midst of a dramatic expansion. India will see an expansion in its working-age population of 300 million between 2010 and 2040, representing one-quarter of the world population increase for this age group. But can India reap a large demographic dividend thanks to this large, youthful and energetic labor force? After all, Asia's successful tiger economies like Japan, Korea, Taiwan and China benefited greatly from demographic dividends.

There are grounds for optimism, based on India's experience over the past few decades. India's youthful demography would have contributed a substantial fraction to India's growth acceleration since the 1980s according to the IMF. ${ }^{8}$ And a demographic dividend could add 2 percentage points to India's annual economic growth rates over the coming three decades. But the prospects for achieving this also seem daunting. Demography is not just a question of quantity. It is also a question of quality. And the quality of India's human capital is one of the poorest in Asia, despite the brilliance of the country's elite.

Only three-quarters of the population are literate according to official statistics. And according to deeper analysis by Indian economist Santosh Mehrotra, only half the nation's population would be "functionally literate". 9 Such an estimate is hardly surprising in light of India's deep poverty, malnutrition, bad health conditions and poor education system. For those 300 million additions to the Indian jobs market to find work, they will also need practical skills. But India has one of the lowest proportions of trained youth in the world. What's more, many of this youth cohort will be Dalits. India will not reap the full benefits of its demographic dividend while ever caste discrimination remains as it is.

India needs to improve its education system at every level. What is most critical is to create an effective Vocational Education Training (VET) system which would cater to the vast majority of India's young population. ${ }^{10}$ But VET has received very limited funding, is of poor quality, and involves little industry collaboration. The result is that just $2 \%$ of the Indian workforce has skills training in formal vocational education. And only another $2 \frac{1}{2} \%$ have received any informal vocational training at all.

The need for VET is perhaps the greatest for rural workers who are flowing into cities in search of opportunity in the construction, manufacturing and service sectors. Without any vocational training, these workers 
end up in the informal sector, working in low-paid jobs and joining the ranks of urban poverty. Even today, India's economy is being held back by a large skills deficit. Its jobs market suffers from shortages of skilled labor, while unemployment and underemployment are also widespread.

Training is only one side of the jobs equation. India also needs business investment to drive industrialization. As dazzling as India's IT and business process outsourcing might be, the sector only employs three million people. Realistically most Indians could not find a place in this sector. Only more serious industrialization could provide sufficient jobs for its growing workforce.

With China now suffering from rising wage costs and a weak demography, India has a window of opportunity to become a manufacturing powerhouse. And India has been attracting large flows of foreign investment thanks in part to the policy reforms of Prime Minister Narendra Modi's government. But India will need to maintain the reform momentum, as it is also competing with countries like Vietnam, Cambodia and the Philippines to attract investment. If India's leaders are unable to tackle the country's chronic problems, the country will not only miss out on a big opportunity. Its demographic opportunity could turn into a demographic time bomb. Social unrest in recent years in Arab countries and elsewhere shows the social and political risks of large populations of unemployed and frustrated youth.

And while India and some other countries face the challenge of managing large youthful populations, Japan has led East Asia's development in terms of its fading fertility. How did Asia's most developed economies end up in such a quandary?

\section{East Asia’s Fading Fertility}

Japan has led the world into the fourth demographic transition where fertility rates below the replacement rate ultimately result in a falling, as well as an aging, population. Today, it's easy to forget that Japan's fertility rate, which is 1.4 children per woman, was over 4 children per woman during the 1930-1950 period.

Japan's experience is not unique in terms of having fertility below the replacement rate. Germany's fertility rate fell below 2.1 in 1971, and today is lower than that of Japan, as is also the case for countries like Greece, Italy, Spain, Portugal and Poland. In sharp contrast, Australia, France, the UK and the US still have fertility rates close to 2. Neither is 
Japan unique in East Asia where Hong Kong, Korea, Macao, Singapore and Taiwan all have fertility rates below Japan.

What are the main factors behind East Asia's collapsing fertility? This is a strange trend according to evolutionary biologists. Normally natural selection produces individuals who are good at converting their resources into lots of fertile descendants.

Fertility rates have fallen dramatically the world over reflecting changes in values and the status of women, education, industrialization, urbanization and the advent of contraception. As we discussed above, a major reason why Japan's fertility rate has fallen so low is that as Japanese women have become more educated, they are also more interested in working, but the Japanese work environment is not very compatible with raising a family. In this context, the declining rate of marriage in Japan is also often attributed to the reluctance of educated Japanese girls to assume all the traditional responsibilities of a Japanese wife, namely raising the family, looking after the husband, running the household and tending to in-laws.

It is also reported that the phenomenon of "hypergamy" is common, where educated Japanese girls will only marry men of equal or higher education or income status to themselves. Hypergamy is becoming increasingly difficult to practice since Japanese girls now achieve, on average, better education results than boys. And the growing prevalence of precarious, non-regular work situations provides a great disincentive for having a family. Only $27 \%$ of men in their thirties with non-regular jobs are married, compared with $66 \%$ of men the same age with permanent jobs, according to government statistics. ${ }^{11}$ And even when they marry, Japanese girls now tend to do so at higher age which affects their reproductive behavior.

Some social commentators argue that Japan is suffering from a "celibacy syndrome" or "sekkusu shinai shokogun". A survey in 2011 found that $61 \%$ of unmarried men and $49 \%$ of women aged $18-34$ were not in any kind of romantic relationship, a rise of almost $10 \%$ from five years earlier. ${ }^{12}$ Another study found that one-third of people under 30 had never dated at all.

Many of the same factors, notably the incompatibility of work and family life, are relevant to East Asia's other low-birth countries. Korean women seem to have much in common with their Japanese counterparts. They are less and less interested in marriage, with a recent government survey revealing that only $46 \%$ of Korean young women being interested in marriage, in contrast to $63 \%$ for young Korean men. 
Soaring housing costs are another factor pushing down fertility in the small, tropical and highly urbanized Chinese-speaking islands of Hong Kong, Macau, Singapore and Taiwan. And like Japan, despite being Asia's most developed economies, these "Chinese islands" are suffering from yawning income inequality and growing poverty in the midst of prosperity, which are having an adverse effect on marriage and fertility.

The cost of education is a deterrent to child birth in some East Asian countries, none more than Korea. The country's national obsession with achieving high grades means that vast amounts of money are spent on private education, especially for after-school tuition. Around threequarters of Korean students undertake after-school education in private schools called hagwons, and many students have private tutors as well. ${ }^{13} \mathrm{It}$ is not surprising that education fees should be cited as the most serious obstacle to having children in a survey undertaken by the Hyundai Research Institute.

One factor preventing fertility rates from falling even further in countries like Korea is the growing "marriage migration", with China, Vietnam and the Philippines being the top sources for Korea's migrant brides. The birth rate among immigrant mothers is higher than that of native Korean women reports Katharine Moon from the Brooking Institution. ${ }^{14}$

What should East Asian governments and societies do about their chronically low fertility rates? Japan's population is already declining, and population decline is on the horizon for Korea, Taiwan and China. This is having dramatic effects on the economy, society, politics and even international relations. All East Asian governments have provided various financial and other incentives to attempt to revive fertility rates. The Japanese and Singaporean governments have even had policies to encourage "dating and mating". But none of these policies have had much effect.

At the heart of East Asia's fading fertility phenomenon is rapid progress in the economy and education of women which has not been matched by commensurate changes in policies and attitudes in the workplace, the family and society at large. We need to have societies which enable us to combine both a work life and a family life. As we discussed in the previous chapter, this means major changes in government policy, corporate/work culture and family life.

A longer term perspective on population decline is also warranted. Of course it seems frightening at first blush, as it evokes images of the possible extinction of the human species. But what we may be seeing is only a partial reversal in the world's population explosion these past two-three 
centuries. ${ }^{15}$ And there are many benefits that could occur. A lower population could ease the immense pressures on the global environment and resources like food, energy and clean water that are resulting from the combination of a large population and high economic growth. In a world with a lower population, workers' wages may be higher as they become a relatively scarce resource.

But the process of adjusting to a lower population will be bumpy and difficult. Villages, towns and even cities might disappear. Japan already has a burgeoning ghost-town problem. There will also be a transitional period of super-aging societies, where small numbers of youth must support large numbers of seniors. And countries with declining populations may lose political power and feel strategically vulnerable.

We cannot leave the issue of Asia's fading fertility without looking at perhaps the most horrific experiment in social engineering the world has ever seen, China's one-child policy which is now being transformed into a "two-child policy".

\section{China's “Two-Child Policy”}

In 2015, when the Chinese government announced its decision to transform its one-child policy into a two-child policy, there was much celebration in the media. With its rapidly aging population, and declining working-age population, demographers and economists had long argued that the one-child policy, whatever its initial merits, was no longer useful to China. But closer scrutiny suggests that the effect of the policy on China's fertility rate may only have been modest, despite the associated horrors of the policy. And that the benefits of a two-child policy may also be modest.

How did China get itself into this "demographic pickle"? China's great leader Deng Xiaoping is revered for his role in opening the Chinese economy to the world. But under his watch, the Chinese government also did some appalling things, like the Tiananmen Square massacre and implementing China's infamous one-child policy.

Population has long been an issue in China. Chairman Mao once famously said "The more people there are, the stronger we are." 16 But Deng and his experts thought differently, even though China's fertility rate had already fallen from 5.8 children per woman in 1970 to 2.8 in 1980 thanks to softer efforts to encourage fewer births. So in 1980, they implemented China's infamous one-child policy. 
Like everything in China, the one-child policy was never implemented uniformly across the nation. Single women are still not allowed to have a child outside of wedlock. Against that, many people have long been allowed to have two children, such as ethnic minorities like the Tibetans and Uighurs, rural residents whose first child was a girl and couples where both parents are only children. This means that the strongest population growth has occurred among groups with the worst access to education and health services - not a good sign for China's economic future.

In short, the one-child policy mainly applied to urban dwellers. But even here there were always inequities. Families who violated the onechild policy law were subject to fines ("social maintenance fees"), which the wealthy could usually afford to pay despite their arbitrary method of calculation. Another way around the system has been "birth tourism" whereby pregnant Chinese women travel to Hong Kong or the US (Saipan is the closest US territory to China, and Chinese citizens do not require a visa to travel there).

Since poor people could not afford to pay fines or travel overseas to give birth, they were all too often subject to horrendous forced abortions, sterilization, contraception and other draconian acts by the family planning agency. According to one estimate, there have been 336 million abortions, 196 million sterilizations and 403 million intrauterine devices inserted since 1971 in China. ${ }^{17}$ There are also many stories of "hidden children" (some 13 million were recorded as lacking birth registration in the 2010 census), transferring excess children to childless couples, infanticide and about 100,000 adoptions by Western families. The Ministry administering the one-child policy behaves like a spy and police organization, with a system of paid informants, "womb police". Human rights lawyers who defend victims of the one-child policy suffer abuses, the most prominent case being the blind lawyer, Chen Guangcheng, who escaped prison to the US.

There is much debate about the real impact of the one-child policy. Official experts claim that it has reduced China's population (today around 1.4 billion), by some 400 million. ${ }^{18}$ It is more likely that it only reduced China's population by about 100 million, a decimal point in such a large country. As Nobel Prize-winning economist Amartya Sen has argued, China's fertility rate would likely have continued its downward trend in tandem with economic development, urbanization and education. ${ }^{19}$ Most other East Asian countries have lower fertility rates than China's 1.7 children per woman-even Thailand's is lower rate at 1.4. As we discussed in 
the previous chapter, the one-child policy may have contributed to China's prenatal gender selection in favor of boys. One of the many social implications of the one-child policy is the "little emperor syndrome" of spoilt one-child brats who are found to be "significantly less trusting, less trustworthy, more risk-averse, less competitive, more pessimistic, and less conscientious individuals" than previous generations. ${ }^{20}$

The Chinese government's decision to transform its one-child policy into a two-child policy is a positive step. But it is a case of too little/too late. Many Chinese urban-dwelling women now would prefer to have just one child. In fact, the evidence to date shows only a small rise in fertility thanks to the two-child policy. Moreover, Chinese women will still have unfair restrictions on their reproductive freedom. And China's dastardly family planning agency will still have too much power over Chinese citizens. There have already been reports of its draconian enforcement of the two-child policy.

Indeed, one factor holding back more significant reform of population policy was the powerful family planning bureaucracy which employs 500,000 full-time and 6 million part-time workers. ${ }^{21}$ It collected over $\$ 3$ billion in fines each year, with over $\$ 300$ billion collected since 1980 . With the new two-child policy, it is still in business! Some commentators like Reggie Littlejohn of Women's Rights Without Frontiers have argued that the one-child policy is a system of social control, masquerading as population control. ${ }^{22}$ And that whether it is a one-child or two-child policy, it is still a system of social control, which the rich can avoid by paying fines, while the poor must obey.

China is in desperate need of sensible population policies to adjust to its aging population, already falling working-age population, and the prospect of a declining population (its population is projected to peak at 1.4 billion in 2030 , before falling to 1.0 billion in 2100). But this means widespread reforms, not just family planning, to address its demographic challenges.

In the following sections, we will discuss some of the economic and social policy implications of population aging.

\section{Economic Costs of Asia’s Aging Populations}

Population aging started to bite hard on the Japanese economy from 1995, when its working-age population (15-64) began falling. With less and less available workers, labor flipped being a positive to a negative force for the economy. Less workers also means lower national saving rates. So 
Japan's annual "potential" economic growth rate fell sharply from over 3\% in the early 1990s, and has been hovering in the 0-1\% range over the past 15 years. ${ }^{23}$ The Organisation for Economic Cooperation and Development (OECD) currently estimates Japan's potential economic growth rate at $1 / 2 \%$ a year. And with Japan's stubborn reluctance to undertake structural reform, there has been no productivity improvement to offset the effect of falling labor supplies. Indeed, population aging would have exacerbated Japan's productivity weakness, as history shows that much innovation emanates from younger workers.

In other words, Japan's population aging, and above all the country's failure to respond effectively to the challenge, is making the country relatively poorer. Looking ahead, Japan's growth potential faces continued downward pressure from population aging. The working-age population is already falling by more than one million per year and could decline by nearly $40 \%$ by 2050 .

As in many things, Korea is following Japanese trends. Korea's workingage population is set to peak in 2016, at 37 million before declining steadily to 33 million in 2030, and perhaps to 22 million in 2060 (total population decline is also on the cards, starting in 2030). ${ }^{24}$ Korea can also expect that its declining working-age population will drag down potential economic growth.

When Japan was struck by declining working-age population, it was already a very prosperous country, with GDP per capita within shooting distance of the US. And while it remains a moderately prosperous country, it has been slowly slipping down the OECD pecking order in terms of GDP per capita. For its part, Korea will be hit by a declining working-age population at an earlier stage than Japan. Today, its GDP per capita is only about half that of the US, and it declining workforce could see it fall slowly further and further behind the US.

But the impact of China's population on the economy is likely to be very much more dramatic. Already in 2012, China's working-age population began its inexorable decline, with a combined decline of 10 million over the 2012-2014 period. Some estimate that China's working-age population could decline by $1 \mathrm{l} / 2 \%$ a year over the coming decades, representing big cumulative whack. But China is being hit by its demographic drama at a much earlier point in its economic catch-up, when its GDP per capita is only $26 \%$ of that of the US.

Thailand is a curious case where the working-age population is also expected to start falling after $2017 . .^{25}$ The country is set to become the 
"old man" of East Asia, with its senior population (aged 65 and over) projected to increase from $8.9 \%$ in 2010 to $19.5 \%$ in 2030 . Thailand is being hit by an aging population at around the same stage of development as China.

In other words, in contrast to the cases of Japan and Korea, China and Thailand are becoming old before they become rich. What to do? The reforms that we discussed in earlier chapters-getting better value out of global value chains, making the most of urbanization's potential, and giving all Asians a chance-would all go a long way toward improving productivity and better exploiting Asia's potential in order to maintain prosperity in aging societies. In this context, the Japanese government has accepted very little of the advice offered from organizations like the OECD and the IMF, or even from Japan's own distinguished like Masahiro Kawai or Naohiro Yashiro. And at this stage, Korea, China and Thailand seem to following Japan's path of inaction.

There is also much that could be done to offer greater work opportunities to Japan's seniors, who have the world's highest life expectancy. After all, much of the challenge of aging comes from failure of things like retirement ages to keep pace with rising life expectancy. But in the context of Japan's rigid seniority-based wage system, Japanese companies have a retirement age of 60 . True many workers are then rehired on irregular contracts at a much lower salary. But a much more flexible labor market would allow seniors to continue their career much later, making important contributions to the economy and society. Korean companies also have a rigid labor market with seniority-based pay, which means that seniors are pushed to retire at a low age. And similarly in China, the retirement age for men is 60 , while that of women is only 50. Plans are reportedly afoot to gradually lift China's retirement age in the coming years. And none too soon! Fast-aging Asian countries also need migrants, an issue that we will take up at the end of this chapter.

The experience of Japan, with over two decades of stagnation under its belt, should be salutary to not only China, Korea and Thailand but also Japan itself. Undertaking structural reform to lift productivity is always important, but even more so in an aging society, where productivity improvements can compensate for effects of a declining workforce. But postponing bitter medicine seems easy in the short term. Vested interests supporting the status quo are always difficult to tackle, be they in a democracy or an authoritarian regime. Unless the Japanese, Korean, Chinese and Thai governments seriously tackle the challenge of aging populations, 
their countries will likely wither away. Asia's demographic dilemmas may be the greatest threat to the realization of an Asian Century.

In the next section, we will examine some of the social policy implications of Asia's aging populations, notably retirement incomes and health expenses. In later sections, we will explore migration, one part of the solution to rapidly aging populations.

\section{Social Policy Challenges of Asia’s Aging Populations}

It's not so long ago that the social policy challenges of aging populations were a non-issue in much of Asia. For one thing, life expectancy was much lower than it is today, and senior citizens made up a very much smaller share of the population.

And only back in 1990, some two-thirds of Asians lived in rural communities, where extended families typically supported their elders. Today, only one-half of Asians live in rural areas, and this figure is rapidly declining as people move to cities in search of more opportunities. As urbanization proceeds, traditional families and communities are breaking down, and being replaced by the nuclear family. While urban migrants send financial remittances to their families in rural areas, over time the Confucian sense of family responsibility is fading, as lifestyles become more individualistic and Westernized. And as fertility rates decline, and family sizes become smaller, supporting one's family can be an enormous burden, especially if you come from a one-child family. Today, a single child can find him or herself with the weighty burden of caring for two parents and four grandparents, the 4-2-1 problem! The Chinese government has responded with a law which requires adult children to visit and care for their aging parents.

All Asian governments are now faced with the responsibility of providing at least some social security, in the form of pensions and health care, to their senior citizens. As poverty declines and prosperity grows, senior citizens have growing expectations. And as education and access to information improves, governments must also take into account public opinion, and govern on the basis of a social contract, even in the case of authoritarian regimes which are scared of social instability. All this means responding to the expectations of senior citizens for a better slice of the rapidly growing economic pie.

So all Asian countries are in the midst of establishing systems of social security which can provide government-financed pensions and health 
care. ${ }^{26}$ Each Asian country will need to develop their own social security systems for their senior citizens in their own historical, political and social contexts. This is a challenging enterprise, as it involves a much greater role of the state than in the past. Revenues must be raised to finance such social security. Systems must be designed which are fiscally sustainable, and which are fair and equitable.

Despite the very rapid progress made, social security systems are still very underdeveloped in Asia and play a much smaller role than in advanced Western countries. Government spending on social protection and health only represents $5 \%$ of GDP compared with over $20 \%$ in the mature advanced economies. While only $22 \%$ of Asia's population above the legal retirement age receive pensions against more than $80 \%$ for advanced economies. ${ }^{27}$ For its part, China has been quick to develop public pension systems, but these mainly apply to urban rather than rural residents. And in the hyper-wealthy Hong Kong and Singapore, public pensions are virtually non-existent. Asian countries have many lessons to draw on from the experience of other countries, especially in Europe and the US. But closer to home the examples of Korea and Japan, two of Asia's most advanced countries, highlight some of the potential pitfalls.

\section{Korea's Shameful Demographic Drama}

Over the past half century, Korea has had the fastest-growing economy among the advanced OECD countries. But looking ahead, the OECD projects that population aging in Korea will also be the fastest in the OECD area. ${ }^{28}$ Already, Korea's life expectancy has skyrocketed from only 53 years in 1960 to 82 in 2015 , while its fertility rate has fallen over the same period over 6 to 1.2 children per woman. This means that Korea's seniors (aged 65 and over) could jump from 11\% of the total population in 2010 to $37 \%$ in 2050 , the second highest among the OECD countries. According to one estimate, if this trend continues, Koreans could be extinct by the year 2750 .

The great shame of Korea's demographic trends is that the generation that created the country's economic miracle is now suffering, and is unable to enjoy the benefits that they so richly deserve. The OECD reports that in 2013 some $50 \%$ of the population aged 65 and over lived in relative poverty, more than three times greater than poverty rate for the nation as a whole. This is in sharp contrast to the OECD area as a whole where relative poverty for the elderly is about the same as for the overall population. 
What's worse is that some $30 \%$ of the elderly population are estimated by the Korean government to be living in "absolute poverty", meaning that their income is below the minimum cost of living. Most of those living in poverty today were reportedly comfortable and prosperous in their careers, and have since fallen on hard times through the tumultuous changes transforming Korea.

Many elderly persons had assumed that their children would provide for them in the traditional Confucian manner. But over the past 15 years, the percentage of children who think they should look after their parents has shrunk from $90 \%$ to $37 \%$, according to government polls, even though their parents may have invested greatly in their education. ${ }^{29}$ Confucian filial piety is now a waning phenomenon. Perhaps the Korean government should follow China in establishing "Confucius laws" which require children to visit or provide for their elderly parents.

So increasing numbers of elderly Koreans are now turning to Christian charity, as they line up outside churches for handouts of cash or food. And violent crime by Korea's elderly is also rising sharply, according Korean police statistics. This is put down to poverty, illness and loneliness. With three-quarters of Korea's elderly poor now living alone, this is hardly surprising. Increasing poverty among the elderly has contributed to a more than doubling of suicide among this group over the past decade-from 35 per 100,000 persons in 2000 to 82 in 2010 . The suicide rate among the Korean elderly is the highest in the OECD area, with the suicide rate of elderly men being double that of women. ${ }^{30}$

In short, the high poverty rate for Korea's elderly population is a major and urgent social problem, which will only get worse in the decades ahead unless something is done. Successive governments have been slow to create an old-age income support system that is necessary in a modern society. The current system provides only paltry benefits to the country's elderly, and is totally inadequate for dealing with the elderly poverty. The new Basic Pension is useful, but not sufficient. The old-age income support system needs a complete overhaul, including increasing taxes, to deal with not only today's challenges, but also to prepare for the country's prospective "silver future".

The Global AgeWatch Index, which ranks countries by how well their older populations are faring, puts Korea at the lowly position of 60th out of the 96 countries covered, way behind Japan at 8th and even the Philippines at 50th and China at 52nd. ${ }^{31}$ If Korea does not get its act together, its inability to manage the challenges of its aging population will 
result in not only a broken society but also a broken economy. This would be a sad ending to the "miracle on the Han River".

We will now turn to the case of Japan where social welfare for the elderly, though not particularly generous, has driven Japan's national government debt to world record levels.

\section{JAPAN's Silver Democracy}

Japan's gross public debt has skyrocketed from 70\% of GDP in 1992 to $220 \%$ in 2016 following 22 years of budget deficits, reports the OECD. And the main driver has been the doubling as a share of GDP of public social spending, most of which goes on pensions, long-term care and health for senior citizens. ${ }^{32}$ Social spending now accounts for more than half of Japan's general government spending. Looking ahead, unless something is done, Japan's public debt could be heading over $600 \%$ of GDP by 2060 !

Some say that this is no big deal. Some $90 \%$ of public debt is held by Japanese institutions, and with low interest rates, the servicing of this debt is not such a great burden. But the OECD is quite rightly worried that at some point markets could lose confidence in Japan. Interest rates could shoot up, adding further to the budget deficit and debt. Although loyalty is a prized Japanese virtue, it may not last forever among Japanese investors. This could lead to capital flight.

Japan desperately needs a serious "plan" to bring its debt under control which should include bringing public social spending under greater control. Lifting the retirement age (currently 65 for men and 63 for women) for receiving public pensions would be a great help. This should be no great burden since Japan still has the world's highest life expectancy at 81 for men and 87 for women. There is also much that could be done to cut back on public health expenditure. Japanese seniors spend enormous amounts of time in expensive hospitals, but often for long-term care rather than medical attention. It is a waste of money to use expensive hospitals as hostels for seniors who are looking for sociable company. And the cost of pharmaceuticals could also be cut back by greater use of generics, for example.

While it is scandalous that Japan's seniors should be bankrupting the country, it is even more scandalous that the working population should be financing this highway robbery. After all, Japan's seniors are the wealthiest segment of Japan's population. This is a case of “intergenerational 
injustice", one generation (Japan's seniors) ripping off another generation (Japan's working-age population), while Japan's working-age population has been suffering from growing poverty and inequality.

Japan is an "intergenerationally unjust" country, ranking the second worst after the US among 29 advanced OECD countries, according to a study by Germany's Bertelsmann Stiftung, that looks at its environmental, economic-fiscal and social aspects. ${ }^{33}$ The study assesses unfair burdens of policy outcomes and their legacies for future generations, and examines the extent to which current socio-economic policies reflect a bias toward today's older generation.

Not surprisingly, Japan ranks the worst of all 29 countries for its public debt. Each Japanese child (between 0 and 14 years old) bore a crushing $\$ 794,000$ in public debt in 2011 . The burden of Japanese children is more than $2 \frac{1}{2}$ times that of Italy and Greece, the next two worst cases. Japan also scores poorly for other criteria like the strong bias of public social spending toward the elderly, and child poverty which restricts future economic and social opportunities.

In other words, Japan has been maintaining its wealth and prosperity at the expense of its children and succeeding generations. How could a country like Japan which, to outside Western eyes, seems to have such a cohesive society, be one of the world's worst countries when it comes to socio-economic justice between generations?

Japan's intergenerational injustice is a product of the country's "silver democracy" or gerontocracy. ${ }^{34}$ In other words, Japan's large senior population has a large and dominant voice over the nation's politics. The share of Japanese voters over 60 years old has more than doubled to $44 \%$ over the past three decades, while the share of voters in their twenties has fallen from $20 \%$ to $13 \%$ since $1980 .{ }^{35}$ This effect is magnified in rural areas, which have smaller population sizes and are dominated by senior citizens. And lastly, senior citizens, who know very well their interests, also have a much higher voting turnout than younger citizens.

In short, this means that it would be electoral suicide for any government to propose a substantial cutting of benefits for seniors, especially if more benefits were to be allocated to the working-age population suffering from poverty and inequality. Many ideas have been put forward to address these issues. Political leaders could appeal to youth to become more involved in politics. The education system could seek to promote greater political literacy among youth. Leaders could undertake a campaign to better inform seniors of the issues at stake, and appeal to their 
reason and altruism. Electoral boundaries could be redrawn more fairly to reduce the influence of seniors in rural districts. Voting rights could be allocated to parents by the number of their children.

But advancing any of these ideas would take great political leadership, something for which Japan is not well known. It is difficult to see Prime Minister Shinzo Abe investing himself in such a campaign, when he is fully occupied by security issues and Abenomics. The other fundamental problem is that any changes to Japan's silver democracy would require the agreement of the country's seniors, something which is unlikely in Confucian Japan where seniors take themselves very seriously!

We will now turn to the issue of immigration in Japan and Korea which could help these countries solve their demographic dilemmas.

\section{JAPAN'S IMMIGRATION IMPERATIVE}

Immigration has become a topic of lively debate in Japan over the past couple of decades, especially since its working-age population began declining in 1995. And Japan's foreign-born population has indeed increased from about $1 \%$ of the total population in 1990 to $2 \%$ today. But Japan has the lowest foreign-born population, as a share of the total, of all the advanced OECD countries except for Mexico. It has always been averse to immigration due to the notions of cultural uniqueness and homogeneity that pervade Japanese thinking.

Japan's immigration policies remain highly restrictive for lower skilled migration. And while Japan is very welcoming, in policy terms, to highly skilled migration, the country has had difficulty attracting such migrants. Many of them choose Hong Kong or Singapore instead. Japan ranked a mere 48 th out of 60 countries for its "attractiveness to foreign-born highly skilled professionals" in a survey by Switzerland's International Institute for Management Development. ${ }^{36}$

The most dynamic response to Japan's immigration imperative has been an internship program which ostensibly gives people from developing countries the opportunity to learn skills they could bring back home. According to the Japanese government, there were close to 200,000 interns in Japan at end-2015, an increase of about 15\% over the previous year, with China, Vietnam and the Philippines being the biggest sources. But as the US government has observed, this program "has effectively become a guest-worker program" as many interns are "placed in jobs that do not teach or develop technical skills", and "some of these workers con- 
tinued to experience conditions of forced labor." ${ }^{37}$ Japan's labor ministry has also found that abuses such as the failure to pay adequate overtime and subjecting workers to unsafe conditions are rampant in this program. ${ }^{38}$

With the continued decline in Japan's working-age population, the country is now beset with labor shortages which are adversely affecting economic growth, as the IMF has argued. ${ }^{39}$ According to a study by Daiwa Institute of Research, there would be labor shortages in the 340,000-660,000 range during FY 2015 and FY 2016, which are cumulatively cutting GDP by some $2 \%$.

According to a survey by the Manpower Group, $81 \%$ of Japanese firms are having difficulties in filling jobs in 2014. This is the highest of all the countries surveyed. Japan's labor shortages are most pronounced in construction, health care, home service and long-term care, as well as restaurants. This presents a particular challenge for the reconstruction following the 2011 triple disaster (earthquake, tsunami and nuclear meltdown), and also with regard to preparing for the 2020 Olympic Games.

The corporate sector and some commentators have been arguing for greater openness to immigration. The government's "Abenomics" program also includes a policy to increase the utilization of foreign workers. The government has implemented some measures for highly skilled foreign professionals and for lengthening the stay of internship migrants from three to five years. But these responses remain very modest.

Looking ahead, there is little end in sight to Japan's labor-shortage problems. Under one scenario, the Japanese government is projecting the labor force to shrink from 66.3 million in 2010 to 56.8 million in 2030 , with economic growth remaining near zero. The Japanese government needs to abandon its ad hoc, reactive approach to immigration. It should develop a comprehensive immigration policy as an integral part of the country's medium term growth strategy.

Taking this step is all the more important as immigration is an important complement to other policy issues. This applies nowhere more than on Abe's signature policy issue-“womenomics". As we mentioned earlier, enhancing women's participation in the economy is constrained by restrictions on immigration of home service and care workers. That makes it difficult for Japanese women to combine work and family life.

Entrepreneurship and innovation are two other areas where Japanese performance has been relatively weak. According to the Global Entrepreneurship Monitor (GEM), Japan's entrepreneurial activity has been very low since GEM started collecting data in 1999. In 2014, Japan 
ranked second lowest among the more than 100 countries surveyed (coming just before Surinam). Many studies have shown that well-managed immigration can be a powerful source of entrepreneurship and innovation. Where would Silicon Valley be without its immigrants?

Prime Minister Shinzo Abe's ambitious target of doubling the stock of foreign direct investment into Japan from the woefully low $4 \%$ of GDP could also be facilitated by greater openness to immigration. Many immigrants arrive with a stock of assets for investment, and can also be useful workers for international companies requiring bilingual staff. And at a time when Japan is seeking to court more diplomatic friends in the Asian region, in the context of geopolitical rivalries, one important friendship gesture would be greater openness to immigration.

Given its concern about the cultural suitability of potential migrants, Japan should also make greater efforts to facilitate the integration of its international students into the economy following their graduation. After a few years study, they are usually at ease with the Japanese language and cultural customs. But less than $10 \%$ of Japan's international students currently seek working visas. Targeting international students as potential immigrants might also improve the attractiveness of Japan as an international education destination.

Japan could also enhance its position as a responsible stakeholder in the international community by reforming its closed-door refugee policy. Few nations are as financially generous as Japan in financing international relief efforts for persons displaced by war, civil strife and natural disasters. Japan is the fourth-largest donor to the UN High Commission for Refugees, with a grant of $\$ 182$ million in 2014. Conversely, few nations are as miserly as Japan in providing physical asylum to refugees. In 2016, the Immigration Bureau only approved 28 of the 10,901 applications $(0.26 \%$ of total) for refugee status. ${ }^{40}$

Is it realistic to think of Japan opening up to immigration as a potential source of economic revitalization?

After all, Prime Minister Shinzo Abe and many parts of his government remain steadfastly against having an immigration policy, citing the social problems experienced in Europe with large-scale immigration. Against that, some government ministers like Shigeru Ishiba and Taro Kono have recently spoken out in favor of increased immigration. ${ }^{41}$ And a recent survey shows that Japanese public opinion may be changing, as $51 \%$ of Japanese respondents said they support Japan accepting foreigners who want to settle, while $34 \%$ were opposed to expanding immigration. ${ }^{42}$ 
Without more serious efforts to address the challenges of its aging population, there is a risk of Japan simply withering away under the weight of poor demographics and the burden of massive public debt and increasing its vulnerability to the growing fragility of its regional security environment. A well-designed immigration strategy could make an important contribution to Japan's future.

\section{Toward a Multicultural Korea}

Unlike its neighbor Japan, Korea has accepted a dramatic increase in immigrants. In 1990, Korea had only 50,000 foreign residents, representing just $0.1 \%$ of the population. By end-2016, this number had leapt to 2.1 million or $4 \%$ of the total population. By the year 2020, foreigners could constitute about $5 \%$ of the total Korean population, and $10 \%$ by the year 2020, according to Brookings' Katherine Moon. ${ }^{43}$ According to a report by the Korea Economic Research Institute, Korea might need up to 15 million migrants by the year $2060 .{ }^{44}$ But in contrast to the past, Korea will also need to attract highly skilled and educated foreign workers, as do Hong Kong and Singapore, in order to maintain its economic dynamism.

Who make up Korea's foreign population, and by what means did they arrive in Korea? Korea's foreign population covers students, white-collar workers, migrant workers in agriculture, low-end industries and service jobs, undocumented workers and foreign brides. Migrants from China, usually ethnic Koreans, are the most important group, accounting for around $40 \%$ of total. There is also a growing number of North Korean defectors, with some 30,000 reportedly living in the South today.

There have been several programs facilitating the arrival of Korea's migrants. ${ }^{45}$ In the early 1990s, there was the Industrial Trainee System. Then from the 2000s, the Employment Permit System (EPS) has permitted the entry of migrants from Southeast and Central Asia to work in labor-shortage industries like agriculture and stockbreeding, fishery, construction and manufacturing. Many of Korea's farming villages are now highly dependent on foreign labor. The EPS is in reality a guest-worker program, with little hope of nationalization, which only allows migrants to work for a limited number of years. EPS guest-workers are not allowed to bring family members and are only allowed to change jobs with the consent of their employer, leaving many trapped and highly vulnerable to abuse. 
Marriage migration constitutes another avenue for migration to Korea. This enables a range of Korean men, such as agricultural workers, the urban poor or lower-middle-class bachelors or divorces, to find wives. Most foreign brides come from China (Korean ethnics), the Philippines, Thailand and Vietnam. Marriage migration is one of the very few paths to Korean naturalization. Marriage migration has become necessary because less and less Korean girls are now interested in marriage. Only 46\% of Korean girls are interested in marriage, compared with $63 \%$ for Korean males, according to a recent survey. In more recent years, there has been an influx of professional expats, foreign teachers and international students. Some students are reportedly attracted by Korea's vibrant pop culture scene.

Today, there are over 820,000 people (including 300,000 foreign spouses) belonging to multicultural families in Korea, a figure which has more than doubled over the past eight years, reports Katherine Moon. Children born with at least one Korean parent are automatically granted Korean citizenship. In rural areas, about $40 \%$ of new marriages per year are between a Korean male and a foreign-born female. And for the Korean nation as a whole, some $10 \%$ of marriages are multicultural.

Despite these new trends toward a multicultural Korea, "New Koreans" suffer from discrimination by the larger society, and from economic insecurity and socio-cultural marginalization. Korean businesses are free to refuse to serve foreigners, something which is not uncommon. Korean identity has long been based on notions of racial and ethnic purity. To put it bluntly, racism is a big problem in Korea, despite reports of Koreans becoming somewhat more accepting of foreigners.

The impact of discrimination is particularly disturbing for children of mixed marriages, very many of whom suffer greatly and do poorly at school. Many multiracial children have difficulty speaking Korean, because their mothers lack fluency. Over time, this could become a major problem unless addressed, as the immigrant mothers have a very much higher birth rate than natives. Other problems are domestic abuse of migrant wives by their Korean family members and labor or marriage brokers. This is creating diplomatic issues with countries like Vietnam. There have been some limited positive developments. In 2012, Jasmin Barcunay Lee, a Philippines-born immigrant, was the first naturalized Korea to win a seat in the National Assembly. Over the years, the government has implemented a number of policies to facilitate the economic and social integration of migrants. It even promotes the idea of Korea becoming a 
multicultural society. And foreign residents were given voting rights in 2006, the first Asian country to do so.

The Korean government has however been taken to task by the UN for not having comprehensive anti-discrimination laws, and for the country's racism and xenophobia. ${ }^{46}$

"As Korean society becomes more exposed to foreigners and migrant workers living in the country, it is important to continue addressing the issue of racism, xenophobia and discrimination," said Mr. Ruteere, UN Special Rapporteur on racism. Mr. Ruteere noted that comprehensive anti-discrimination legislation would allow the appropriate institutions to play a more significant role in receiving complaints from victims, investigate and issue relevant recommendations for the government to follow up.

He encouraged the South Korean authorities to fight racism and discrimination through better education, as well as ensuring that the media is sensitive and conscious of the responsibility to avoid racist and xenophobic stereotypes and that perpetrators are punished where appropriate. He also called on the government to improve legislation on employment in order to offer a better protection to migrant workers and their families, and encouraged the authorities to ratify the International Convention on the Protection of the Rights of All Migrant Workers and Members of Their Families.

One of the most egregious examples of migrants' rights abuses in Asia is that of the exploitation and forced labor of migrant agricultural workers in South Korea, as reported by Amnesty International. ${ }^{47}$ Listen to the voice of NT, a 35-year-old woman from Cambodia, who was working at a fruit and vegetable farm in South Jeolla province. "I was supposed to have a day off every other Saturday. But from April to June I worked every day without rest from $3 \mathrm{am}$ to $7 \mathrm{pm}$. Otherwise rest days were given arbitrarily by the boss, who didn't want me to be free on Saturdays, because he didn't want me befriending other Cambodians. He was probably afraid that others would find out about my long work hours."

Agricultural migrant workers in Korea typically enter under the EPS. Their labor is important to the survival of farms throughout the country. Despite this, a significant number of employers exploit migrant agricultural workers who endure excessive working hours, underpayment, discrimination and poor living conditions. Many are also denied a weekly paid rest day and annual leave. Severe restrictions on migrants' ability to change jobs prevent many from escaping exploitative conditions. In 
addition, the Labor Standards Act excludes agricultural workers from legal protections covering working hour, breaks and weekly rest days.

Amnesty's report reveals how the majority of migrants interviewed were trafficked for exploitation and were working in conditions of forced labor. Most were coerced into working under conditions to which they did not agree, most commonly through threats and violence. Amnesty also highlights shortcomings in the redress mechanisms, finding that many people who sought help from the authorities were actively discouraged from taking complaints forward. Consequently, many unscrupulous employers have been allowed to exploit migrant agricultural workers with virtual impunity. Until the rights of these migrants are protected in practice, the EPS will continue to be synonymous with a system of labor exploitation, argues Amnesty International.

Amnesty's findings are supported by evidence compiled by the National Human Rights Commission of Korea. Concerns about the treatment of migrants under Korea's EPS have also been raised by a number of UN bodies, but the Korean government has consistently failed to implement their recommendations. Korea has not ratified a number of relevant international conventions, namely: the UN Protocol to Prevent, Suppress and Punish Trafficking in Persons, Especially Women and Children; and the ILO Conventions on Forced or Compulsory Labour, and Abolition of Forced Labour.

When compared with cosseted Japan, Korea's opening to immigration to help address its demographic drama is very impressive. But the Korean government and many Korean citizens do not treat their migrants as human beings, with human rights. They treat them more as a technical solution to a demographic and economic problem. Now that Korea has been a member of the OECD for some 20 years, it is high time that Korea adhered to the values of this organization, notably respect for human rights and pluralist democracy. Much more serious efforts to promote an open and inclusive multicultural society would not only provide great benefits in terms of social cohesion and stability. It would also foster a more creative and dynamic economy.

Asia's politics are being buffeted by its demographic dilemmas and a vast array of other factors. As we explore in the next chapter, fixing Asia's 
flawed politics will be crucial in Asia's quest for economic development and middle-class societies.

\section{Notes}

1. Zielenziger, Michael (2007). Shutting Out the Sun: How Japan Created its Own Lost Generation.

2. The Japan Times. Japan home to 541,000 young recluses, survey finds, 7 September 2016.

3. BBC. China's 'leftover women', unmarried at 27, 21 February 2013.

4. UN. 2015 Revision of World Population Prospects.

5. UNFPA, UNESCO and WHO 2015. Sexual and Reproductive Health of Young People in Asia and the Pacific. A review of issues, policies and programmes. Bangkok: UNFPA.

6. ADB. Asian Development Outlook 2011 Update. Preparing for Demographic Transition.

7. UN. World Population Prospects. 2017 Revision.

8. Aiyar, Shekhar and Ashoka Mody. The Demographic Dividend: Evidence from the Indian States. IMF Working Paper. WP/11/38.

9. Mehrotra, Santosh, Ravi Raman, Neha Kumra, Kalaiyarasan, Daniela Röß. Vocational Education and Training Reform in India: Business Needs in India and Lessons to be Learned from Germany. Working Paper. Bertelsmann Stiftung.

10. German President visits Bertelsmann Stiftung conference on creating vocational education system in India, 10 February 2014.

11. Wall Street Journal. Why Japan's Economy Is Laboring, 8 April 2016.

12. The Guardian. Why have young people in Japan stopped having sex?, 20 October 2013.

13. BBC. South Korea's schools: Long days, high results, 2 December 2013.

14. Moon, Katharine H.S. South Korea's demographic changes and their political impact. Brookings, 26 October 2015.

15. Friedman, George. Population Decline and the Great Economic Reversal. Geopolitical Weekly, 17 February 2015. Stratfor.

16. Hayoun, Massoud. Understanding China's One-Child Policy. The National Interest, 15 August 2012.

17. Financial Times. Data reveal scale of China abortions, 16 March 2013.

18. Chang, Gordon G. Shrinking China: A Demographic Crisis. World Affairs, May/June 2015.

19. Sen, Amartya. Women's Progress Outdid China's One-Child Policy. New York Times, 2 November 2015.

20. Cameron, Lisa, Nisvan Erkal, Lata Gangadharan, and Xin Meng. Effects of China's One Child Policy on its children. Science Daily, 10 January 2013. 
21. Wall Street Journal. China to Move Slowly on One-Child Law Reform, 17 November 2013.

22. Morse, Anne Roback. Police Brutality Happens Every Day in China. Population Research Institute, 6 May 2015.

23. OECD. Economic Survey of Japan 2017.

24. Wall Street Journal. South Korea May Need Up to 15 Million Immigrants, Study Says, 15 December 2014.

25. Guilford, Gwynn. Thailand's joining Japan and Korea as one of the "old men" of Asia. Quartz, 23 August 2013.

26. ADB. Pension Systems in East and Southeast Asia. Edited by Donghyun Park, 2012.

27. Jain-Chandra, Sonali, Kalpana Kochhar and Tidiane Kinda. Reducing Inequality in Asia: Sharing the Growth Dividend. IMF Blog, 24 May 2016.

28. OECD. Economic Survey of Korea 2014.

29. Korea Joongang Daily. Only piety is no longer enough, 6 July 2015.

30. The Economist. Elderly suicides in South Korea-Poor spirits, 7 December 2013.

31. helpage.org. Global AgeWatch Index 2015.

32. OECD. Economic Survey of Japan 2017.

33. Bertelsmann Stiftung (2013). Intergenerational justice in aging societies. A Cross-national Comparison of 29 OECD Countries.

34. Yashiro, Naohiro. How to overcome the Silver Democracy in Japan? Presentation to Brookings Conference, 3 December 2014.

35. Harney, Alexandra. Japan's Silver Democracy: The Costs of Letting the Elderly Rule Politics. Foreign Affairs, 18 July 2013.

36. Kodama, Takashi. Japan's Immigration Problem. Daiwa Institute of Research, 29 May 2015.

37. US Department of State. Trafficking in Persons Report 2016.

38. Nikkei Asian Review. Abuses rampant in foreign trainee program, Japan labor ministry finds, 18 August 2016.

39. Ganelli, Giovanni, and Naoko Miake. Foreign Help Wanted: Easing Japan's Labour Shortages. IMF Working Paper. WP/15/181.

40. nippon.com. Japan's Closed-Door Refugee Policy, 19 May 2015.

41. The Japan Times. Government weighs immigration to maintain population, boost workforce, 6 January 2016.

42. Asahi Shimbun. 51\% of Japanese support immigration, double from 2010 survey, 18 April 2015.

43. Moon, Katharine H.S. South Korea's demographic changes and their political impact. Brookings, 26 October 2016.

44. The Korea Times. Why Korea must be more open to immigration, 20 March 2015. 
45. Oh, Jung-Eun, Dong Kwan Kang, Julia Jiwon Shin, Sang-lim Lee, Seung Bok Lee, and Kiseon Chung. Migration Profile of the Republic of Korea. International Organisation of Migration. IOM MRTC Research Report Series No. 2011-01.

46. UN News Centre. Republic of Korea: UN rights experts urges adoption of anti-discrimination law, 9 October 2014.

47. Amnesty International. South Korea: End rampant abuse of migrant farm workers, 19 October 2014.

Open Access This chapter is licensed under the terms of the Creative Commons Attribution 4.0 International License (http://creativecommons.org/licenses/ by $/ 4.0 /$ ), which permits use, sharing, adaptation, distribution, and reproduction in any medium or format, as long as you give appropriate credit to the original author(s) and the source, provide a link to the Creative Commons license and indicate if changes were made.

The images or other third party material in this chapter are included in the chapter's Creative Commons license, unless indicated otherwise in a credit line to the material. If material is not included in the chapter's Creative Commons license and your intended use is not permitted by statutory regulation or exceeds the permitted use, you will need to obtain permission directly from the copyright holder.

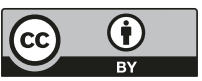

